Sanjin Ivanović ${ }^{1}$

Zorica Vasiljević ${ }^{2}$

University of Belgrade, Faculty of Agriculture, Belgrade

Lana Nastić

Institute of Agricultural Economics, Belgrade, Serbia
ORIGINAL SCIENTIFIC ARTICLE doi:10.5937/ekonomika2001053I

Received: January, 29. 2020. Accepted: February, 30. 2020.

\title{
PRODUCTIVITY OF SERBIAN MILK PRODUCERS BASED ON FADN DATA ${ }^{4}$
}

\begin{abstract}
Productivity is one of the basic economic principles needed for successful farm operations. The goal of this research is to analyze productivity of Serbian milk producers involved in FADN sample. Therefore, the research has been based on publically available FADN data and FADN methodology. Applying number of indicators authors discussed close relation between farm size and productivity. Besides, relation between productivity and economic efficiency of Serbian farms specialized in milk production is presented. The results indicated number of cows necessary to improve productivity of Serbian farms oriented towards milk production.
\end{abstract}

Key words: milk production, productivity, FADN, economic efficiency

JEL classification: Q12, Q14, D13

\section{ПРОДУКТИВНОСТ РАДА ФАРМИ ЗА ПРОИЗВОДЮУ МЛЕКА У СРБИЈИ НА ОСНОВУ ФАДН ПОДАТАКА}

\begin{abstract}
Апстракт

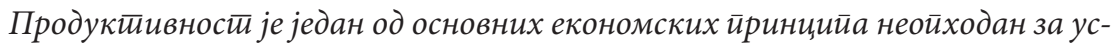
иешно функционисане йољойривредних газдинсииава. Циь овог истираживаға је да анализира ирродукииивности ироозвођача млека у Србији који су укључени у ФАДН узорак. Због йога је истираживане базирано на јавно досииуиним ФАДН йодаиима и ФАДН мейодологији. Примеюујући већи број йоказайельа ауйори су анализирали блиску везу између величине газдинстивва и иродук-

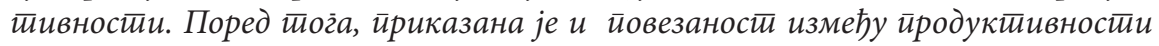
и економичностии газдинстиава у Србији која су сиецијализована за ироизводюу млека. Добијени резулитайи указују на број крава који је неоиходан да се унайреди ирродукииивносй фбарми усмерених на ирроизводюу млека у Србији.
\end{abstract}

Кључне речи: ироизводюа млека, ирродукииивносй, ФАДН, економичносии

\footnotetext{
${ }^{1}$ sanjinivanovic@agrif.bg.ac.rs, ORCID: 0000-0002-2005-9910

2 vazor@agrif.bg.ac.rs, ORCID: 0000-0002-3076-3303

${ }^{3}$ lana_n@iep.bg.ac.rs, ORCID: 0000-0003-1939-0718

${ }^{4}$ Paper is financed by the Ministry of Education, Science and Technological Development of the Republic of Serbia.
} 


\section{Introduction}

Cattle production is the most important livestock production in Serbia, but its significance has decreased in the recent period. Having in mind changes in statistical methodology applied as of 2006, data for the previous period are not presented in this research. Anyway, it is noticeable that the total number of cattle has decreasing tendencies from 1,096,000 in 2006 to 878,000 in 2018. Besides, the number of milking cows decreased from 600,000 in 2006 to 423,000 in 2018, as well as the total beef production which also decreased in the observed period (Statistical Office of the Republic of Serbia for period from 2006 to 2018). Therefore, capacities for accommodation of cattle in Serbia are only $36 \%$ used (Radivojević, D., 2014). The reasons for such tendencies are numerous, but the most important one is variability of the market prices of outputs (milk, meat) and prices of inputs (primarily prices of animal feed) in cattle production. Besides, agricultural policy in Serbia has been changing frequently, so it is hard to predict future levels of state support. Nevertheless, changes in Serbian agricultural policy are usually favorable for livestock production. At the moment, Serbia’s agricultural policy is not harmonized with Common Agricultural Policy (CAP) because there are significant differences concerning direct incentives (Božić and Papić, 2017).

Volume of milk production in Serbia remained rather stable in the long run (1,500 million liters per year), which is caused by an increase in milk production per cow. According to the official data published by the Serbian Statistical Office and authors' calculation, the milk production per cow increased by 881 liters per cow in period from 2006 to 2018. Milk production in Serbia is primarily based on family farms that are very small considering the number of heads (Table 1). Farms having less than 10 heads represent $89.94 \%$ of the total number of cattle farms.

Table 1. Serbian farms dealing with cattle production

\begin{tabular}{|c|c|c|}
\hline Number of heads & Number of cattle farms & Structure (\%) \\
\hline $1-2$ & 88,457 & 49.90 \\
\hline $3-9$ & 70,977 & 40.04 \\
\hline $10-19$ & 12,121 & 6.84 \\
\hline $20-29$ & 2,914 & 1.64 \\
\hline $30-49$ & 1,701 & 0.96 \\
\hline $50-99$ & 810 & 0.46 \\
\hline$>=100$ & 272 & 0.15 \\
\hline Total & 177,252 & 100.00 \\
\hline
\end{tabular}

Source: Statistical Office of the Republic of Serbia (2013).

To become more competitive with the EU dairy producers, Serbian farmers should increase their size and improve production technology, which is related to productivity increase. Therefore, the goal of this research is to analyse various aspects of productivity of farms directed to milk production. 


\section{Theoretical backgrounds and literature review}

Some authors enlist marketing and financing conditions as the most important ones for development of the entire livestock production (Ivanović, Jeločnik and Bekić, 2009). Similarily, problems related to financing and marketing are the most important problems of small and medium enterprises in Serbian agriculture (Simonović, Đuričić and Miletić, 2017). Results of research performed by Ivanović, Kovačević and Vasiljević (2018) indicated that beef production in Serbia would not be profitable without state subsidies. Besides, Subić, Vasiljević and Ivanović (2009) underline the importance of education of agricultural producers to enable them to identify development possibilities, while Nastić, Ivanović and Jeločnik (2014) determined that the majority of farmers have lack of knowledge related to farm management in the contemporary business environment. It is important to point out that pastures and meadows significantly participate in the structure of utilized agricultural area in Serbia (approximately 20.7\%) and have great potential to decrease production costs. Nevertheless, they are not used enough in all forms of livestock production, such as cattle, sheep and goat production (Ivanović, L., 2018).

Vertical integration and cooperation in the area of milk production and processing is not developed enough. On the other hand, research presented by Končar, Marić and Vukmirović (2018) indicated that these principles increase income, productivity and profitability of all participants. One of important issues is small participation of food and live animals in total Serbian export. According to Marković (2019) it is only around 16\% of Serbian export (average for period 2012 - 2017). One of possibilities to improve dairy farming is production of autochthonous food products, especially in areas where such products are registered. Discussing promotion of products with geographical indication Puškarić, Kuzman and Maksimović (2016) mentioned cow-milk kashkaval from Pirot, cow-milk cheese from Sjenica and alike. There are also some less known problems which should be solved, such as the relation between selection goals for dairy cows and the way milk price is determined (the problem is described by Ivanović, Stanojević, Nastić and Jeločnik, 2014). According to Nastić and Bekić (2015) Serbian farmers also have to pay attention to Nitrates Directive which is related to Serbian accession to the EU, because the Directive is related to additional investments in facilities for environmental protection.

At the same time, majority of premises for cattle productions are outdated (Radivojević, Ivanović, Nastić and Jeločnik, 2014). While Ivanović S., Ivanović L. and Bratić (2008) stated a significant relation between investments in cattle production and business results of the analyzed farms, Ivanović (2008) determined that larger cattle farms have better efficiency of investments. Similarily, Gogić, Ivanović and Nastić (2012) found out that investments in dairy farms' enlargement in Serbia are economically efficient.

Introduction of FADN system (Farm Accountancy Data Network) in Serbia and its use was discussed by Vasiljević (2011), Vasiljević, Zarić and Ivkov (2012) and Ivkov, Vasiljević and Ghelfi (2013). Figurek and Vukoje (2011) stated that FADN is appropriate basis for development of agricultural policy and for control of its effects. Result of research (also based on FADN data) dealing with farm size in the EU (Ivanović, S., 2018) show that a change in farm size is related to an increase of indicator Family Farm Income/Family Work Unit (for all farms included in the EU FADN sample). When the production types within cattle production in the EU are mutually compared it is determined that milk production has much higher FNVA/AWU (Farm Net Value Added per Annual Work Unit) than extensive forms of cattle production (Nastić, Marković and Ivanović, 2017). 


\section{Research methodology and Hypotheses}

The analysis of productivity of milk producers in Serbia has been performed on the basis of FADN data for 2015, because these are the most recent officially published data. In 2015 FADN sample consisted of 1,104 farms, while $19.50 \%$ of sample was farms specialized in milk production (Farm Return, 2015). The FADN sample for milk production within Farm Return is officially divided in various ways. If number of cows is considered, it is divided into four farm sizes (less than 5 cows, 5 to 10 cows, 10 to 20 cows, more than 20 cows). The other way officially used to divide the sample is according to various economic sizes of milk farms (EUR 4-8,000; EUR 8-25,000; EUR 25-100,000; more than EUR 100,000). According to agricultural census conducted in 2012 majority of livestock units (considering all types of production) are present on farms having economic size 4,000 - 8,999 EUR, 8,000 - 14,999 EUR and more than 100,000 EUR (Cvijanović, Subić and Paraušić, 2014). According to the same research only $2.9 \%$ of all farms in Serbia are specialized exclusively for milk production.

It is also possible to present number of cows (expressed in livestock units) for each above mentioned economic size of a farm. Having in mind that analyzed farms are specialized in milk production, cows dominate in total number of livestock units (Table 2).

Table 2. Milk farms in the sample according to economic size and number of cows

\begin{tabular}{|l|c|c|}
\hline \multicolumn{1}{|c|}{ Economic size of farms } & $\begin{array}{c}\text { Number of milking cows per } \\
\text { farm (in livestock units) }\end{array}$ & $\begin{array}{c}\text { Total number of livestock } \\
\text { units per farm }\end{array}$ \\
\hline EUR 4-8,000 & 3.70 & 5.36 \\
\hline EUR 8-25,000 & 8.39 & 11.85 \\
\hline EUR 25-100,000 & 22.26 & 33.67 \\
\hline More than EUR 100,000 & 71.25 & 108.53 \\
\hline Average & 6.43 & 9.28 \\
\hline
\end{tabular}

Source: Farm Return (2015)

The most complex way of analysis used in Farm Return (2015) is to divide farms specialized in milk production into three groups according to their level of productivity. The basic assumption of the analysis is that productivity is expressed by an indicator - Farm Net Value Added per Annual Work Unit (FNVA/AWU - SE 425). The first group of farms represents $25 \%$ of farms with low level of indicator SE 425 . The second group represents $50 \%$ of farms having medium level of this indicator, while $25 \%$ of farms having high level of indicator SE 425 are included in the third group. This approach will be used in this research to analyze various aspects of productivity of milk producers involved in FADN sample.

To describe changes in productivity authors used number of indicators such as Annual Work Unit (AWU), Family Work Unit (FWU), Farm Net Value Added/Annual Work Unit (FNVA/AWU) etc. The research starts from the hypothesis that there is a close relation between increase in farm size and level of productivity of milk producers. An additional hypothesis is that level of indicator SE 425 is related to level of indicator SE 132 (Total input / Total output). 


\section{Research results and Discussion}

If various levels of productivities are compared with number of milking cows and total number of livestock units, it could be noticed that increase of level of indicator SE 425 is closely related to the increase of farm size (Table 3). This is the case because only big farms have capacity to invest in modern building and equipment needed to facilitate the production and make labor more productive. Besides, only big farms are able to apply modern production technology, to provide wellbeing of animals, appropriate sanitary conditions and veterinarian care, to offer balanced fodder of good quality etc.

Table 3. Milk farms in the sample according to levels of SE 425

\begin{tabular}{|c|c|c|}
\hline $\begin{array}{c}\text { Farm Net Value Added per Annual } \\
\text { Work Unit }\end{array}$ & $\begin{array}{l}\text { Number of milking cows per } \\
\text { farm (in livestock units) }\end{array}$ & $\begin{array}{c}\text { Total number of livestock } \\
\text { units per farm }\end{array}$ \\
\hline Low level & 6.60 & 10.08 \\
\hline Medium level & 10.43 & 14.56 \\
\hline High level & 28.92 & 44.73 \\
\hline
\end{tabular}

Source: Farm Return (2015)

Besides, it is determined that farms having low level of productivity have the lowest milk production per cow (3,895 liters) while farms with high productivity have milk production per cow 5,645 liters per year (Figure 1). If total number of Annual Work Unit is considered, there are no big differences between observed levels of productivity (low level - 2.75 AWU in total; medium level - 2.36 AWU in total; high level - 2.59 AWU in total). On the other hand, milk production per annual work unit significantly increases with productivity level going from low to high, while milk production per Family Work Unit (unpaid labor) increases even more. It is also important that number of AWU per cow decreases while number of cows per AWU increases with increased level of productivity (Figure 2).

Figure 1. Milk production per cow and per AWU in 2015(liters)

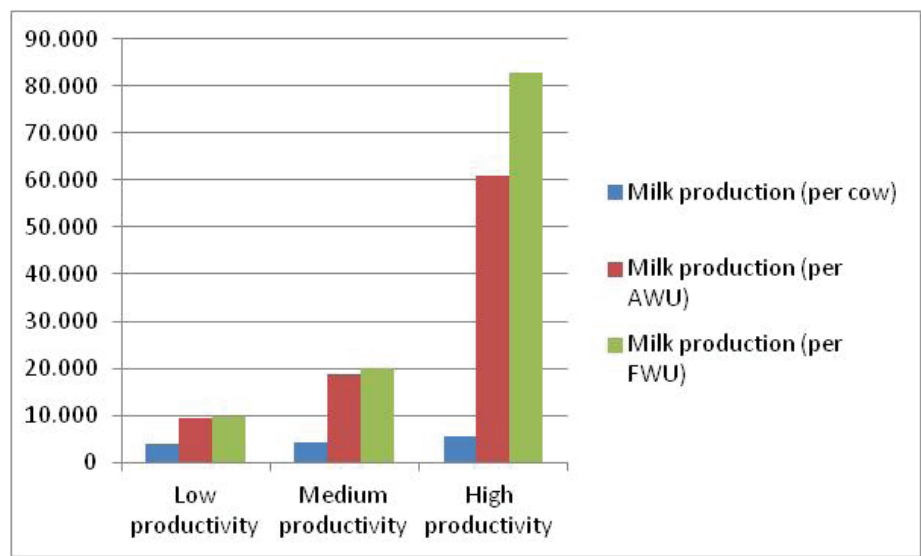

Source: Farm Return (2015) and authors' calculation. 
Figure 2. Relation between number of cows and AWU in 2015

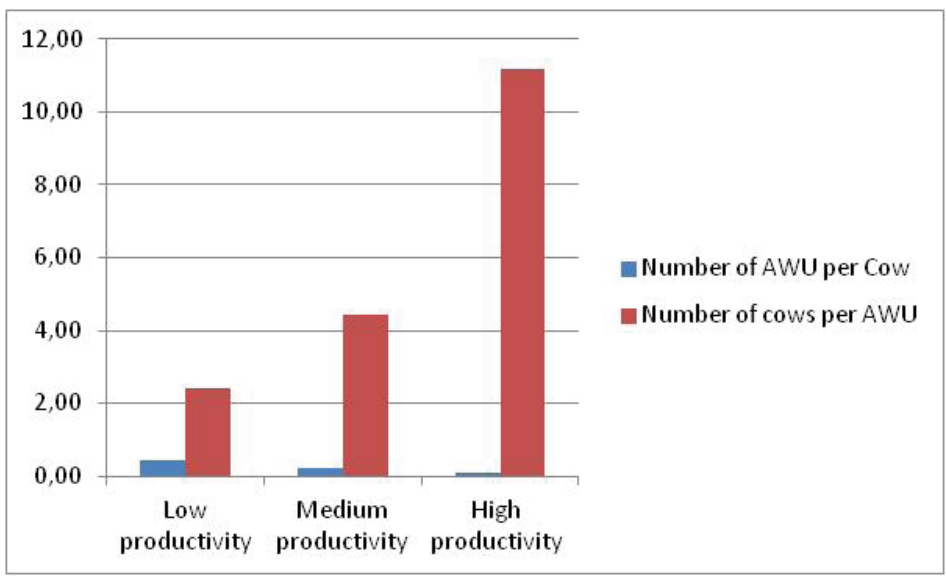

Source: Farm Return (2015) and authors' calculation.

Consequently, highly productive farms are more orientated towards paid labor (Figure 3). They use nine times more paid labor comparing to the least productive farms. Nevertheless, in all observed cases work of family members (unpaid labor) dominate within total AWU. Difference in productivity influences total Utilized Agricultural Area (Figure 4) per farm (which ranges from 11.54 hectares to 40.41 hectares), amount of UAA per AWU (ranges from 4.20 to 16.60 hectares per AWU) as well as amount of UAA per FWU (from 4.30 hectares to 20.51 hectares).

Figure 3. Annual Work Unit (AWU) for various farm sizes in 2015

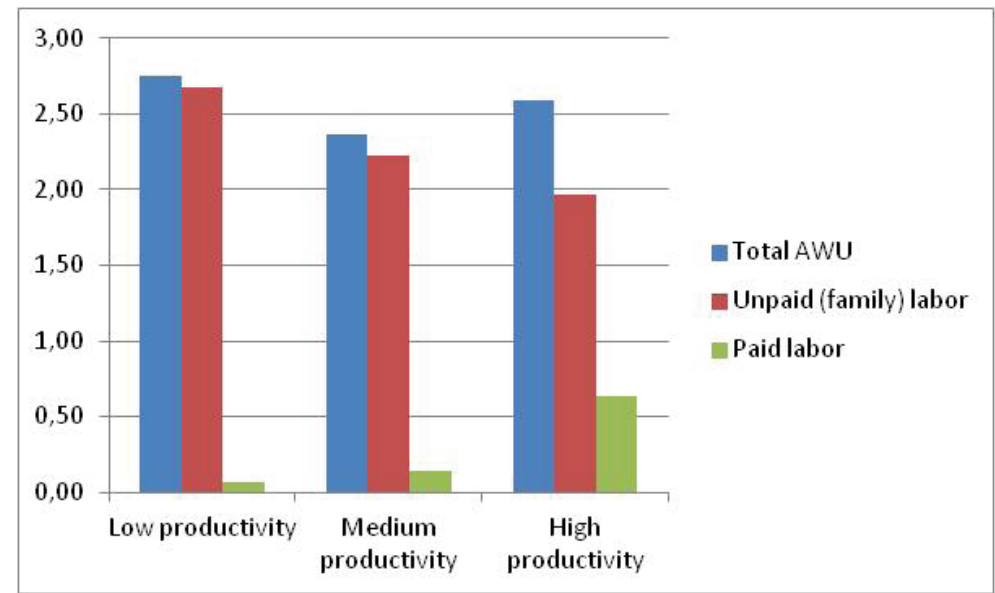

Source: Farm Return (2015) and authors' calculation. 
Figure 4. Utilized Agricultural Area (UAA) for various farm sizes in 2015

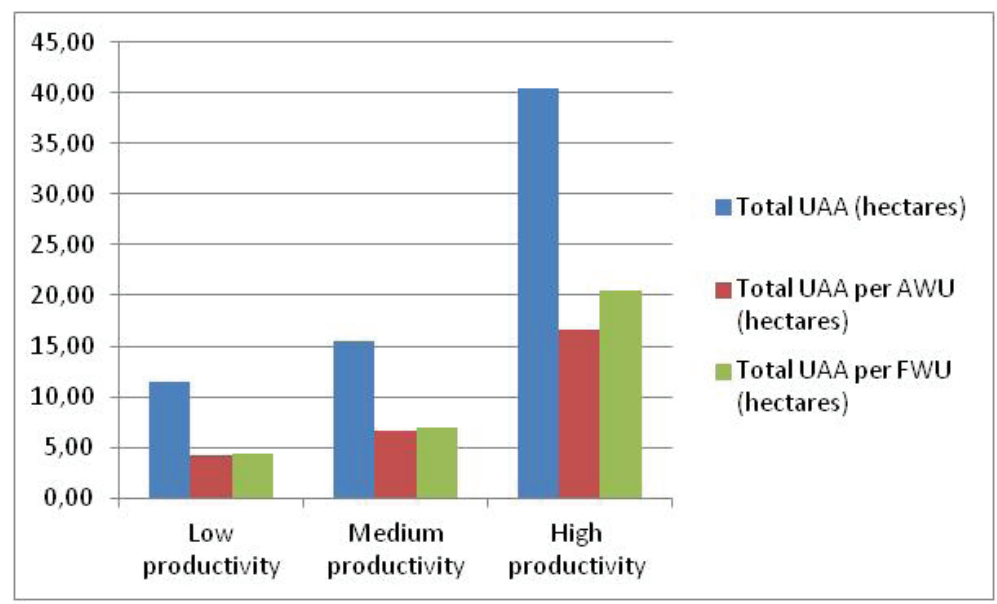

Source: Farm Return (2015) and authors' calculation.

Considering value of livestock production per livestock unit (LU), per Annual Work Unit, and per Family Work Unit the biggest improvement was recorded for indicator related to family labor (Figure 5). The same pattern is noticeable concerning the most important productivity measures (Figure 6) which are FNVA/AWU as well as Family Farm Income / Family Work Unit (FFI/FWU). Later indicator is the most sensitive because high productive (the biggest farms) are enlarging amount of their Family Farm Income, while at the same time engagement of family labor is decreasing.

Figure 5. Value of livestock production per LU, AWU and FWU in 2015 (000 RSD)

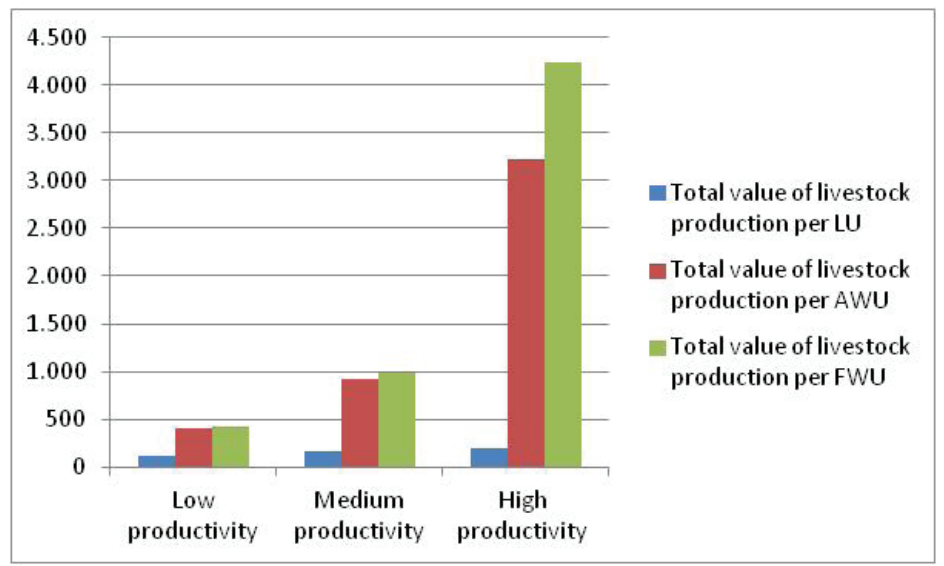

Source: Farm Return (2015). 
Figure 6. Indicator FNVA/AWU (SE 425) in 2015 (000 RSD)

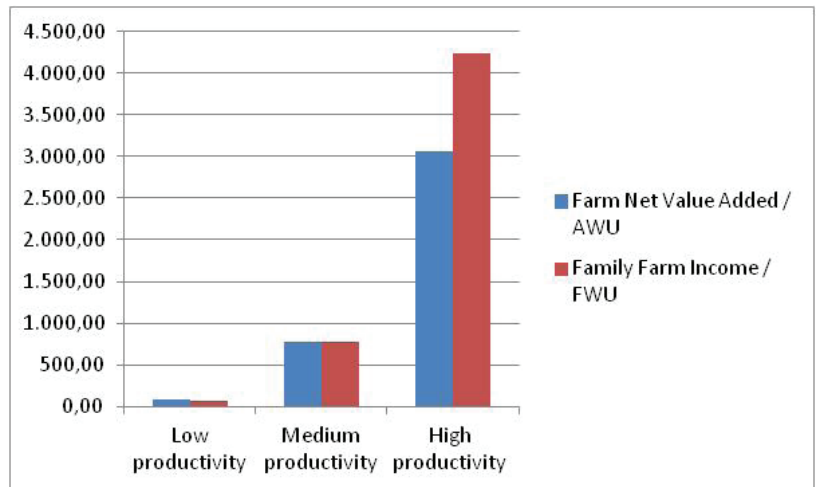

Source: Farm Return (2015) and authors' calculation.

Having in mind that productivity is closely related to economic efficiency of agricultural production, indicator Total input / Total output (SE 132) for the smallest (the least productive) milk producers is just over 1, which means that sustainability of such farms in long run is questionable. On the other hand, more productive farms have acceptable levels of SE 132 (Figure 7).

Figure 7. Indicator SE 132 in 2015

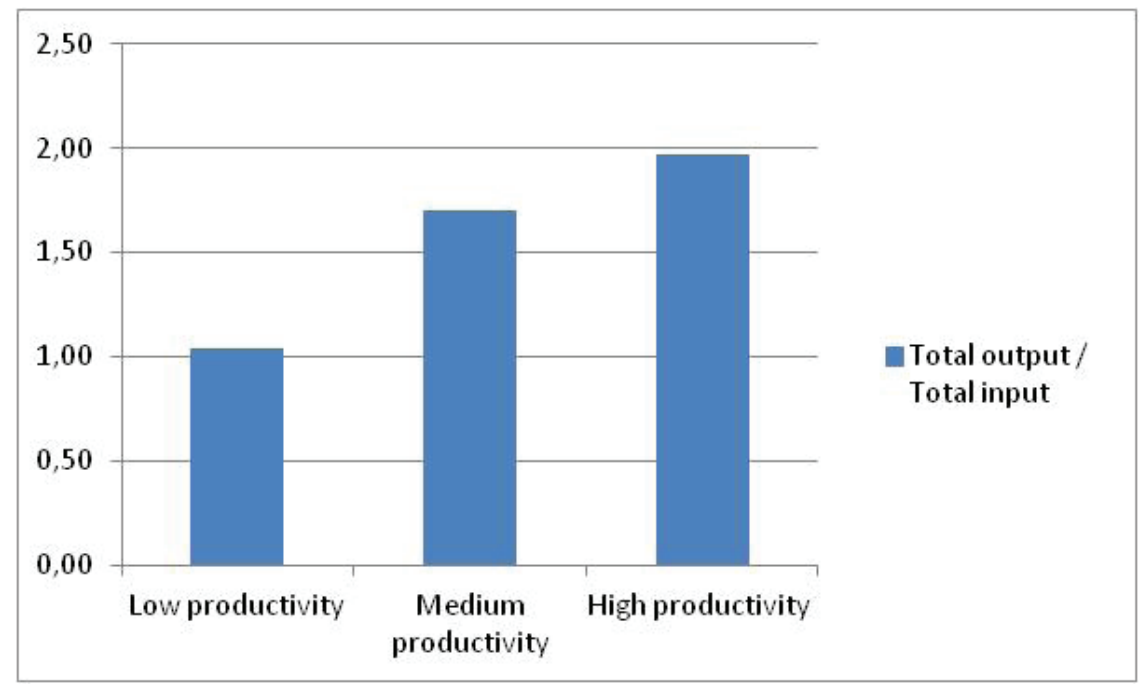

Source: Farm Return (2015) and authors' calculation.

To perform additional analysis of factors affecting performance of observed farms, it is necessary to analyze structure of income (Table 4), and structure of total costs (Table 5). All farms specialized in milk production have value of livestock production higher than $50 \%$ of total production value. Farms with higher level of productivity are characterized by higher 
participation of livestock production in total production, while participation of other gainful activities is decreasing. Considering participation of fodder in total costs it could be noticed that they dominate among other production costs. Farms having the highest productivity are producing the lowest percentage of purchased feedstuffs on the farm.

Table 4. Structure of production value

\begin{tabular}{|l|r|r|r|r|r|r|}
\hline \multirow{2}{*}{ Indicator } & \multicolumn{2}{|c|}{ Low } & \multicolumn{2}{c|}{ Medium } & \multicolumn{2}{c|}{ High } \\
\cline { 2 - 7 } & $(000$ RSD $)$ & \multicolumn{1}{c|}{$\%$} & $(000$ RSD $)$ & \multicolumn{1}{c|}{$\%$} & (000 RSD) & \multicolumn{1}{c|}{$\%$} \\
\hline Value of crop production & 1,017 & 47,04 & 1,419 & 39,18 & 4,950 & 37,26 \\
\hline Value of livestock production & 1,121 & 51,85 & 2,185 & 60,32 & 8,335 & 62,74 \\
\hline Value of other gainful activities & 24 & 1,11 & 18 & 0,50 & 0 & 0,00 \\
\hline Total value of production & 2,162 & 100,00 & 3,622 & 100,00 & 13,285 & 100,00 \\
\hline
\end{tabular}

Source: Farm Return (2015)

Table 5. Structure of costs

\begin{tabular}{|l|r|r|r|}
\hline Indicator & \multicolumn{1}{|c|}{ Low } & \multicolumn{1}{c|}{ Medium } & \multicolumn{1}{c|}{ High } \\
\hline Total costs (000 RSD) & 2,264 & 2,431 & 8,235 \\
\hline Purchased fodder for grazing stock (000 RSD) & 1,132 & 1,378 & 4,221 \\
\hline Farm-produced feedstuffs for grazing stock (000 RSD) & 928 & 1,079 & 3,016 \\
\hline Participation of purchased fodder in total costs (\%) & 50.00 & 56.68 & 51.26 \\
\hline Participation of farm produced feedstuffs in total costs (\%) & 40.99 & 44.39 & 36.62 \\
\hline Participation of farm produced in purchased (\%) & 81.98 & 78.30 & 71.45 \\
\hline
\end{tabular}

Source: Farm Return (2015)

\section{Conclusion}

The results of this research confirmed the hypotheses and indicated significance of productivity for economic results of farms specialized in milk production. Productivity is closely related to farm size, so that the farms having near to 30 milking cows and around 45 total livestock units are showing the best results. In such a way this analysis gives approximate number of cows needed for Serbian milk producers to achieve satisfying business results. Level of productivity is closely related to economic efficiency of production, as well. Therefore, increase in indicator of productivity SE 425 (FNVA/AWU) causes improvement of indicator SE 132 (Total input / Total output). Having all that in mind, policy makers should support enlargement of milk producing farms as well as use of highly productive cows. Future research should be directed towards possibilities for additional decrease of fodder costs, having in mind that they dominate within total costs. 


\section{References}

Božić, D., Papić, R. (2017). Reforma ZAP (2014-2020) i komparacija sa instrumentima agrarne politike Srbije. Anali Ekonomskog fakulteta u Subotici, 53(38), 037-049.

Cvijanović, D., Subić, J., Paraušić, V. (2014). Poljoprivredna gazdinstva prema ekonomskoj veličini i tipu proizvodnje u Republici Srbiji. Republički zavod za statistiku, Beograd.

Farm Return (2015). Ministarstvo poljoprivrede i zaštite životne sredine. Retrieved from: https://www.fadn.rs/wp-content/uploads/2016/08/FADN-Serbia_Farm_ Return2015.pdf.

Figurek, A., Vukoje, V. (2011). Značaj mreže računovodstvenih podataka za kreiranje agrarne politike. Anali Ekonomskog fakulteta u Subotici, 47(25), 187-195.

Gogić, P., Ivanović, S., Nastić, L. (2012). Investments in dairy farms enlargement in Serbia: A tool for poverty reduction in rural areas. African Journal of Business Management, 6(1), 422-429.

Ivanović, L. (2018). Mogućnosti razvoja ekstenzivnih oblika stočarske proizvodnje u Srbiji. Doktorska disertacija, Poljoprivredni fakultet, Univerzitet u Novom Sadu.

Ivanović, L., Jeločnik, M., Bekić, B. (2009). Possibilities for Increment of Live Stock Breeding Competitiveness on the Territory of Belgrade City. $113^{\text {th }}$ Seminar of European Association of Agricultural Economists "The role of knowledge, innovation and human capital in multifunctional agriculture and territorial rural development", December 9-11, Belgrade, Serbia, pp. 191-200.

Ivanović, S. (2008). Economic Efficiency of Investments in Cattle Production at Family Farms. Journal of Agricultural Sciences, 53(3), 223-234.

Ivanović, S. (2018). Effectiveness of crop and livestock farms size change in the EU. XXIII Symposium on Biotechnology, Proceedings, Publisher: University of Kragujevac, Faculty of Agronomy, Čačak, Serbia, 9-10 March, pp. 555-560.

Ivanović, S., Ivanović, L., Bratić, S. (2008).Influence of cattle production type to investments in contemporary housing and equipment (results of questionnaire). Economics of Agriculture, 2/2008, 189-196.

Ivanović, S., Kovačević, D., Vasiljević, Z. (2018). Profitability and Riskiness of Cattle Fattening Operation in Serbia. Proceedings of the $9^{\text {th }}$ International Agricultural Symposium "AGROSYM 2018", Jahorina, Bosnia and Herzegovina, 4-7 October 2018, pp. 1975-1980.

Ivanović, S., Stanojević, D., Nastić, L., Jeločnik, M. (2014). Determination of Economic Selection Index Coefficients for Dairy Cows. Economics of Agriculture, 61(4), 861-875.

Ivkov, I., Vasiljević Z., Ghelfi, R. (2013). Establishment of the Serbian FADN institutional framework. Book of proceedings, 50th Anniversary Seminar, Agriculture and Rural Development - Challenges of Transition and Integration Processes, pp. 336-354. 
Končar, J., Marić, R., Vukmirović, G. (2018). Izazovi vertikalne integracije učesnika lanca snabdevanja prehrambenim i organskim proizvodima nacionalnog porekla. Anali Ekonomskog fakulteta u Subotici, 54(40), 149-169.

Marković, M. (2019). Analysis of Comparative Advantages of Serbian Exports at the Sectoral Level. Ekonomika, 65(3), 55-64.

Nastić, L., Bekić, B. (2015). Harmonization with EU Regulation Regarding Environmental Protection in Livestock Production. In: Andrei, J.V., Ion, R.A., Turek, R.A. (ed.), Green Economic Structures in Modern Business and Society (pp. 102-120). Hershey, Pennsylvania, USA: IGI Global.

Nastić, L., Ivanović, S., Jeločnik, M. (2014). Management Challenges on Family Farms in Republic of Serbia. Proceedings from VI International Scientific-Practical Conference "Modern problems of national economic development". Stavropol State Agrarian University, Faculty of Accounting and Finance, Stavropol, Russian Federation, March 13-14, pp. 17-23.

Nastić, L., Marković, T., Ivanović, S. (2017). Economic Efficiency of Extensive Livestock Production in the European Union. Economics of Agriculture, 64(3), 1219-1230.

Puškarić, A., Kuzman, B., Maksimović, B. (2016). Impact of Promotional Activities on the Development of Autochthonous Food Products Market. Ekonomika, 62(4), 86-94.

Radivojević, D. (2014). Poljoprivredna mehanizacija, oprema i objekti. Popis poljoprivrede 2012, Poljopriveda u Republici Srbiji. Republički zavod za statistiku, Beograd.

Radivojević, D., Ivanović, S., Nastić, L., Jeločnik, M. (2014). Capacities of the facilities for livestock accommodation in the Republic of Serbia. Proceedings of $17^{\text {th }}$ Scientific Conference "Current Problems and Tendencies in Agricultural Engineering", Institut za poljoprivrednu tehniku, Poljoprivredni fakultet Beograd -Zemun, 12.12.2014, pp. 178-186.

Simonović, Z., Curčić, N., Miletić, V. (2017). Neki problem razvoja malih i srednjih preduzeća u poljoprivredi Srbije. Anali Ekonomskog fakulteta u Subotici, 53(37), 057-069.

Statistical Office of the Republic of Serbia (2013). Popis poljoprivrede 2012 (Census of Agriculture 2012 in the Republic of Serbia), Knjiga II, Poljoprivreda u Republici Srbiji, Beograd.

Statistical Office of the Republic of Serbia (2020). Statistical publications.

Statistical Office of the Republic of Serbia (2007). Statistical Yearbook of the Republic of Serbia. Belgrade.

Subić, J., Vasiljević, Z., Ivanović, S. (2009). Education of agricultural producers intended to improve farm operations and management. $113^{\text {th }}$ Seminar of the European Association of Agricultural Economists (EAAE) "The role of knowledge, innovation and human capital in multifunctional agriculture and territorial rural development", Thematic Proceedings, 9-11 December 2009, Belgrade, Serbia, pp. 257-265. 
Vasiljević, Z. (2011). Uspostavljanje mreže računovodstvenih podataka na porodičnim poljoprivrednim gazdinstvima u Srbiji. Izazovi evropskih integracija, Tema broja "Poljoprivreda Srbije u procesu evropskih integracija", 2012/19, 27-40.

Vasiljević, Z., Zarić, V., Ivkov, I. (2012). Recording of accountancy data the family farms in Serbia. Third International Scientific Symposium "Agrosym Jahorina 2012". November 15-17, 2012. Jahorina, Faculty of Agriculture, pp. 599-604. 